\title{
An Easy Way To Distinguish DNA from Protein: An Experiment for General Chemistry
}

\author{
Dulce López-Valentín,* Liliana Pulido-Cordoba, and Arturo Chavez-Reyes
}

Science Education, Cinvestav Monterrey, Via del conocimiento 201, Parque de Investigacion e Innovacion Tecnologica (PIIT), Autopista al aeropuerto Km 9.5, Nuevo Leon, Apodaca 66600, Mexico

\section{Supporting Information}

\begin{abstract}
We propose a classroom experiment to complement a classroom activity described by Ellis et al. in this Journal. In the Ellis activity students extracted long polymer fibers from the cells of common foods. In this experiment, the identity of the long polymer fibers as either DNA or protein can be determined by doing three accessible, inexpensive, and easy tests. Two of the tests, temperature and the acid-medium effect, are based on the physicochemical properties of DNA (reversible denaturalization), and the third test is a qualitative determination of proteins (absent in DNA). The results of these three tests provide evidence to distinguish the isolated molecule of DNA from proteins that might look like DNA.
\end{abstract}

KEYWORDS: First-Year Undergraduate/General, High School/Introductory Chemistry, Biochemistry, Physical Chemistry, Laboratory Instruction, Hands-On Learning/Manipulatives, Food Science Nucleic Acids/DNA/RNA, Proteins/Peptides
$\mathrm{E}$ llis et al. ${ }^{1}$ described a classroom activity that illustrates DNA extraction from animal and plant tissues. In this activity, students extract DNA from the cells of common foods (beef, liver, and onions) in three steps: (i) breaking the cell membrane with mechanical crushing and by the addition of a buffered detergent solution, (ii) separating and removing the cell debris by centrifugation, and (iii) precipitating the DNA by adding cold ethanol. Students obtain long polymer fibers of DNA forming a fluff-like layer in the last step. What is the evidence that supports that the long polymer fibers are DNA? How can we prove that those white fluffs are DNA without using a spectrophotometer? Students may wonder about the presence of proteins in the extract or even think that the precipitate is protein instead of DNA, so how can we distinguish DNA from proteins?

Proteins are the most abundant biological macromolecules, occurring in all cells and in all parts of cells. Proteins are polymers of amino acids, with each amino acid residue joined to its neighbor by a specific type of covalent bond, the peptide bond. Proteins can be easily broken down (hydrolyzed) to their constituent amino acids by a variety of methods, so that the earliest studies of proteins focused on the free amino acids derived from them. Twenty different amino acids are commonly found in proteins and they have a carboxyl $(-\mathrm{COOH})$ group and one amino $\left(-\mathrm{NH}_{2}\right)$ group attached to the same carbon atom (the $\alpha$-atom). Amino acids differ from one another in their side chains, or $\mathrm{R}$ groups, which vary in structure, size, and electrical charge. Proteins are described in terms of four levels of organization; primary, secondary, tertiary, and quaternary. A description of all covalent bonds (mainly peptide bonds and disulfide bonds) linking amino acid residues in a polypeptide chain defines its primary structure. The most important element of the primary structure is the sequence of amino acid residues. The secondary structure refers to particularly stable arrangements of amino acid residues giving rise to recurring structural patterns (helices and pleated sheets). The tertiary structure describes all aspects of the threedimensional folding of a polypeptide. When a protein has two or more polypeptide subunits, their arrangement in space is referred to as the quaternary structure. ${ }^{2}$ Knowing the main physicochemical characteristics of $\mathrm{DNA}^{1}$ and proteins, the following could be done to distinguish between these two molecules.

We propose a classroom experiment to complement the activity described by Ellis et al. ${ }^{1}$ The experiment was used in a secondary school. About $30 \mathrm{~min}$ are enough to complete the activity. The identity of the long polymer fibers as either DNA or protein can be ascertained by doing three accessible, inexpensive, and easy tests. Two of the tests, temperature and the acid-medium effect, are based on the physicochemical properties of DNA (reversible denaturalization), and the third test is a qualitative determination of proteins (absent in DNA). The results of these three tests will provide evidence to distinguish the isolated molecule of DNA from proteins that might look like DNA.

Published: August 13, 2012 


\section{EXPERIMENT}

\section{Overview}

In the three experiments, the physicochemical properties of DNA are compared against those of protein. The DNA sample has been "purified" in a previous lab (try it using strawberries or bananas). ${ }^{1}$ For each of the three tests, the obtained fiber is spooled around a glass rod or a wood stick (barbecue stick), similar to spaghetti spooled around a fork, and then placed inside a test tube. The same wood stick can be used as a spatula. The obtained precipitated DNA sample is enough to do the three assays. For the protein sample, and to have a protein that looks similar to DNA, the egg white (ovalbumin or albumin) of one egg is used.

\section{Temperature Effect}

Distilled water, $2 \mathrm{~mL}$, is added to a precipitated DNA sample contained in a test tube (labeled T-a). The same procedure is repeated with $0.5 \mathrm{~mL}$ of egg white sample (labeled T- $b$ ). The contents of both tubes are gently mixed and placed into a beaker of boiling water for $2 \mathrm{~min}$. The test tubes are removed from the bath with tweezers and the contents gently mixed again. Students look carefully at the two test tubes and take notes for a later discussion.

\section{Acid-Medium Effect}

Acid, $2 \mathrm{~mL}$ of $0.1 \mathrm{M} \mathrm{HCl}$, is added to a precipitated DNA sample contained in a test tube (labeled A-a). The tube is closed with a clean rubber stopper and the contents are shaken for $2 \mathrm{~min}$. The same procedure is repeated with $0.5-\mathrm{mL}$ of egg white sample (labeled A-b). Students look carefully at the two test tubes and take notes for a later discussion.

\section{Qualitative Protein Assay}

Biuret solution, 5 drops, is added to a precipitated DNA sample contained in a test tube (labeled P-a). The tube is closed with a clean rubber stopper and the contents are shaken for $1 \mathrm{~min}$. The same procedure is repeated with $0.5-\mathrm{mL}$ of egg white sample (labeled P- $b$ ). Students look carefully at the two test tubes and take notes for a later discussion. The Biuret solution can be purchased or made by the students. ${ }^{3}$

\section{HAZARDS}

Laboratory coats and suitable eye protection must be worn while undertaking this experiment. Students must follow the general safety precautions required in chemistry laboratories. The students should examine the MSDS sheets for the specific hazards associated with the chemicals used in the experiment. Handle all solvents and liquid reagents with care. Hydrochloric acid, Biuret solutions, and sodium hydroxide are corrosive when concentrated. All waste must be collected and disposed according to safety regulations.

\section{RESULTS AND DISCUSSION}

The results obtained in each test are shown in Figure 1. From the proposed tests, the students can conclude that DNA- and protein-containing solutions can be differentiated by raising the solution temperature, which leads to denaturation of the molecules. DNA is soluble when placed in a boiling water bath caused by the separation of its double strand and resulting in a clear solution. However, albumin of the egg white changes its conformation caused by heat to a globular random aggregation as a clot, resulting in a cloudy suspension (Figure 1A).

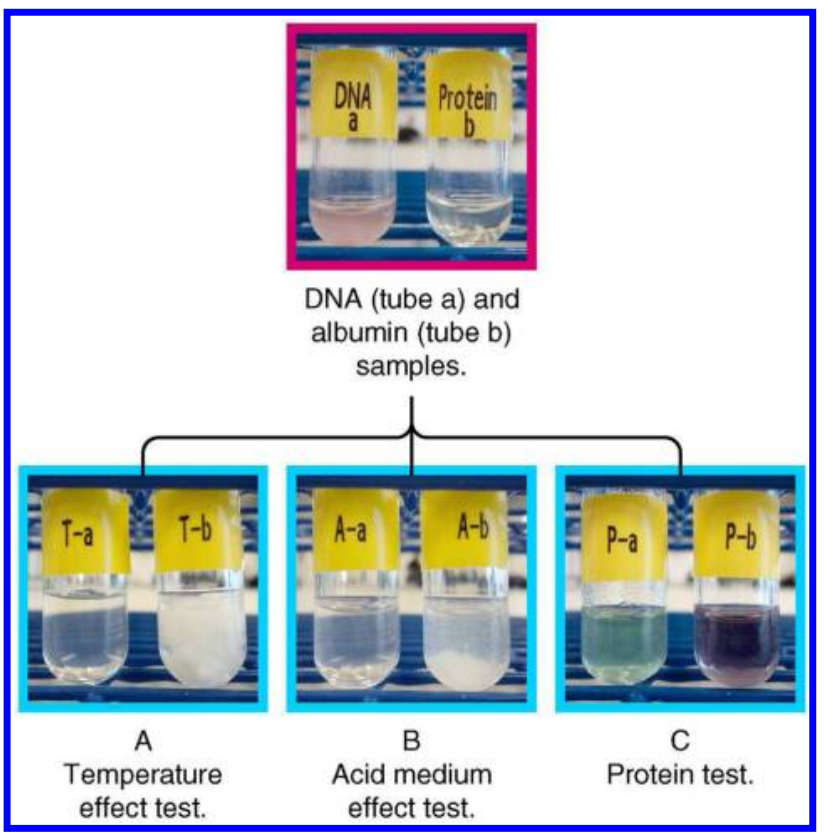

Figure 1. The results of the (A) temperature effect test, (B) acid medium effect test, and (C) protein test on DNA (tube a) and albumin (tube b) samples.

The denaturing effect of a change in $\mathrm{pH}$ is also observed in DNA and proteins as they react differently when they are in contact with an acidic medium. The DNA double strand is separated and solubilized in $0.1 \mathrm{M} \mathrm{HCl}$. However, the natural conformation of the egg white is altered and acquires a new conformation as a filamentous white aggregate (Figure 1B).

Proteins form a complex with copper salts in alkaline solution. ${ }^{4}$ The reagent with these characteristics is known as Biuret reagent. When a protein reacts with this reagent, a distinctive purple-violet complex is formed (Figure 1C). It is a simple method to specifically identify the presence of proteins; pure DNA samples should give a negative reaction. Biuret and the Folin phenol ${ }^{5}$ reactions are the most popular methods to identify proteins.

\section{CONCLUSION}

It is important to give evidence to students whenever possible. Extracting DNA from common foods provides students with hands-on opportunities to engage with a visualization of genetic material that can be later supported by its identification. The temperature effect, acid-medium effect, and protein identification assay are three accessible, inexpensive, and easy tests to distinguish DNA from proteins in the classroom.

\section{ASSOCIATED CONTENT}

S Supporting Information

Notes for the instructor about general physicochemical properties of DNA and proteins. This material is available via the Internet at http://pubs.acs.org.

\section{AUTHOR INFORMATION}

\section{Corresponding Author}

*E-mail: dulce122@hotmail.com; dmlopez@cinvestav.mx.

Notes

The authors declare no competing financial interest. 


\section{ACKNOWLEDGMENTS}

The authors are grateful for financial support provided by Cinvestav-Monterrey.

\section{REFERENCES}

(1) Nordell, K. J.; Jackelen, A. L.; Condren, S. M.; Lisensky, G. C.; Ellis, A. B. J. Chem. Educ. 1999, 76, 400A-400B.

(2) Nelson, D. L.; Cox, M. M. Lehninger. Principles of Biochemistry, 4th ed.; W. H. Freeman and Company: New York, 2005; pp120-132.

(3) Copper sulfate, $3 \mathrm{~g},\left(\mathrm{CuSO}_{4} \cdot 5 \mathrm{H}_{2} \mathrm{O}\right)$ is dissolved in $100 \mathrm{~mL}$ of distilled water. A portion, $25 \mathrm{~mL}$, of the $3 \%$ solution is slowly added to $1000 \mathrm{~mL}$ of $10 \%$ sodium hydroxide $(\mathrm{NaOH})$ solution, while stirring constantly. Resch, B., Ed. The Biology Teacher's Handbook, 4th ed.; NSTApress: Arlington, VA, 2009; p 319.

(4) Mehl, J. W.; Pocovska, E.; Winzler, R. J. J. Biol. Chem. 1949, 1 (177), 13-21.

(5) Lowry, O. H.; Rosebrough, N. J.; Farr, A. L.; Randall, R. J. J. Biol. Chem. 1951, 193, 265-275. 